\section{CONTINUING MEDICAL EDUCATION}

\section{Basal Cell Carcinoma}

Seum Chung

Department of Plastic and Reconstructive Surgery, National Health Insurance

Corporation Ilsan Hospital, Goyang, Korea

Correspondence: Seum Chung

Department of Plastic and Reconstructive Surgery, National Health Insurance Corporation Ilsan

Hospital, 100 Ilsan-ro, Ilsandong-gu, Goyang 410-719, Korea

Tel: +82-31-900-0560, Fax: +82-31-900-0343, E-mail: schung@nhimc.or.kr

No potential conflict of interest relevant to this article was reported.

Received: 9 Feb 2012 • Revised: 16 Feb 2012 • Accepted: 17 Feb 2012 pISSN: 2234-6163 • eISSN: 2234-6171

http://dx.doi.org/10.5999/aps.2012.39.2.166 • Arch Plast Surg 2012;39:166-170

Copyright (C) 2012 The Korean Society of Plastic and Reconstructive Surgeons

This is an Open Access article distributed under the terms of the Creative Commons Attribution

Non-Commercial License (http://creativecommons.org/licenses/by-nc/3.0/) which permits

unrestricted non-commercial use, distribution, and reproduction in any medium, provided the

original work is properly cited.

\section{LEARNING OBJECTIVES:}

After reviewing this article on basal cell carcinoma, the reader should be able to

1) Review the epidemiology and causes

2) Describe the common clinical findings and classification

3) Describe treatment methods

4) Discuss the prognosis

\section{EPIDEMIOLOGY}

Basal cell carcinoma (BCC) is the most common type of skin cancer $(75 \%$ to $80 \%)$ and the most common of all cancers (more than one out of every three new cancers). Seventy to eighty percent of BBC occurs in the head and neck region, followed by the trunk (about 25\%), and penis, vulva, or perianal skin (about 5\%). It is more common in light-skinned individuals (type 1 or type 2 skin) with a family history of BCC and increases in incidence closer to the equator or at higher altitudes. Incidence is relatively low in Asians, Blacks, and Hispanics. The current male-to-female ratio is approximately 2.1:1. BCC incidence increases with age; about $5 \%$ to $15 \%$ of BCC cases occur in patients aged 20 to 40 years, and the incidence is more than 100 -fold in persons aged 55 to 70 years than in those aged 20 years or younger. BCC accounts for about $0.1 \%$ to $2 \%$ of all patient deaths due to cancer [1].

\section{CAUSES}

BCC is usually caused by a combination of cumulative ultravio- let (UV) light exposure and intense, occasional UV exposure, and overexposure to $\mathrm{X}$-rays or other forms of radiation. $\mathrm{BBC}$ also occurs in association with basal cell nevus syndrome, xeroderma pigmentosum, albinism, epidermodysplasia verruciformis, Gardner's syndrome, and nevus sebaceous. Patients receiving immunosuppression therapy are at increased risk for BCC. $\mathrm{BBC}$ occurrence in scar tissue has also been reported $[2,3]$.

\section{PATHOPHYSIOLOGY}

Basal cell carcinomas develop in the basal cell layer of the epidermis. Exposure to sunlight may cause DNA damage (thymine dimer formation). While DNA repair removes most UV-induced damage, not all cross-links are excised. Thus, cumulative DNA damage occurs. Apart from the mutagenesis, sunlight decreases immune surveillance for new tumor cells [4].

A gene commonly found to be mutated in $\mathrm{BCC}$ is the $\mathrm{PTCH}$ gene. A PTCH gene mutation at chromosome 9q22.3, which inhibits the hedgehog signaling pathway, is found in patients with basal cell nevus syndrome (Gorlin syndrome). Similarly, a mutation in the SMO gene (hedgehog pathway) also causes basal cell carcinoma [5].

\section{CLINICAL FEATURES}

The most commonly found clinical feature of BCC is an elevated tumor with a pearly and translucent margin and telangiectasia. The color may vary widely from nearly normal skin color to erythematous to violaceous and may also be pigmented. BCC may also resemble noncancerous skin conditions such as eczema or psoriasis. The majority of these cancers occur on areas of skin that are regularly exposed to sunlight or other ultraviolet radiation. They may also appear on the scalp [6].

\section{CLASSIFICATION}

Basal cell carcinoma has many clinical forms and is commonly classified into the following types [7]:

- Nodular basal cell carcinoma (classic BCC) (Fig. 1): most common type ( $50 \%$ to $80 \%$ ) and occurs most often on sunexposed areas of the head and neck ( $85 \%$ to $90 \%$ ).

- Cystic basal cell carcinoma (Fig. 2): characterized by domeshaped, blue-gray cystic nodules.

- Morphoeic, morpheaform or cicatricial basal cell carcinoma (Fig. 3): $2 \%$ to $6 \%$ of BBCs; aggressive variant with distinct white sclerotic plaque and histological appearance.

- Infiltrative basal cell carcinoma (Fig. 4): aggressive type characterized by deep infiltration. 


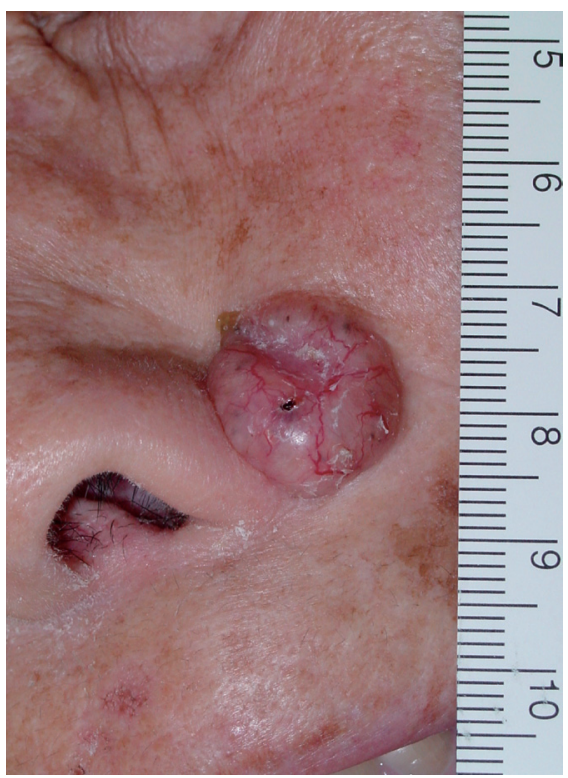

Fig. 1.

Nodular basal cell carcinoma (classic $\mathrm{BCC})$.

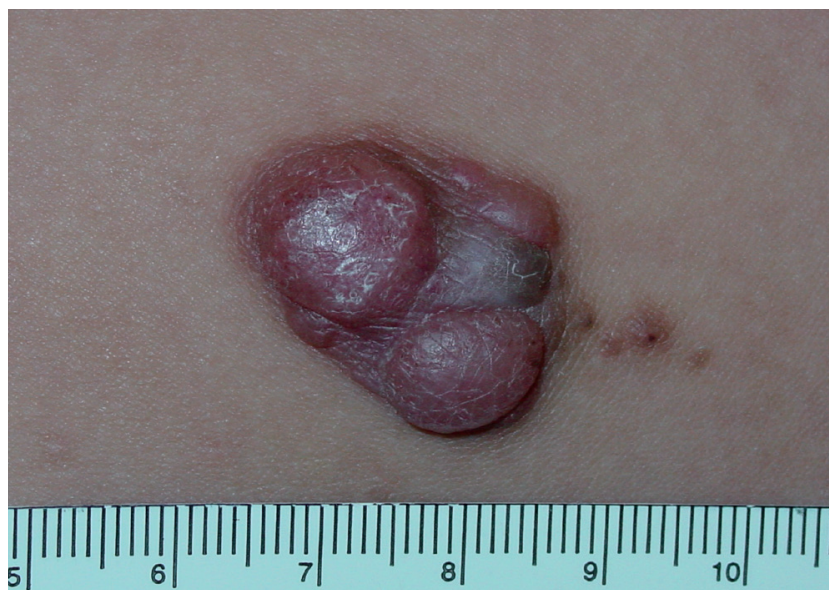

Fig. 2.

Cystic basal cell carcinoma.

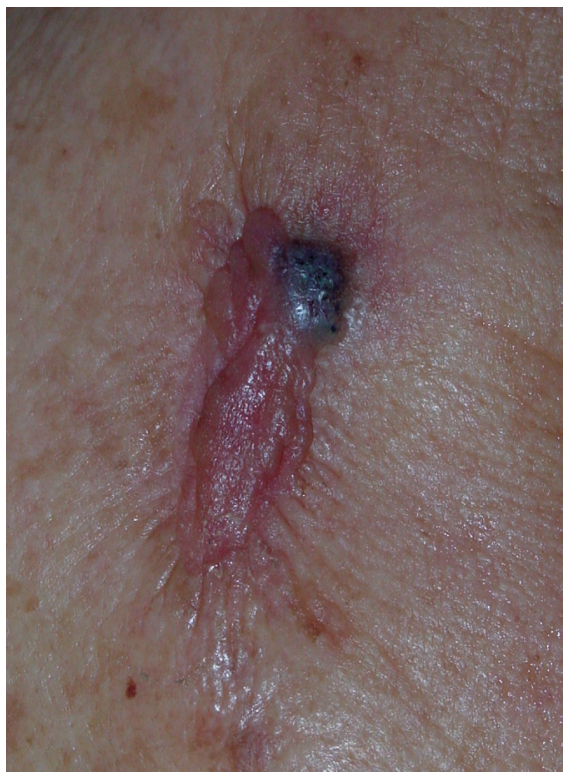

Fig. 3.

Morphoeic, morpheaform or cicatricial basal cell carcinoma.

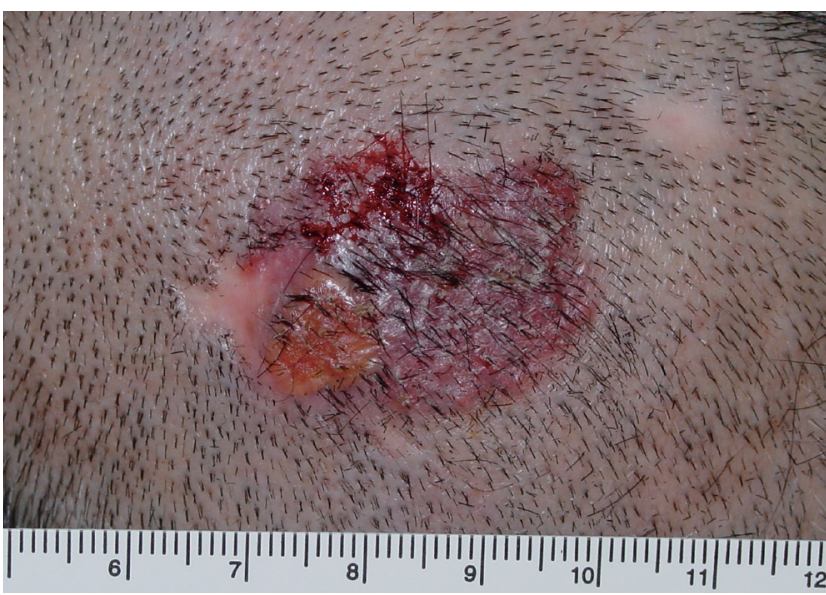

Fig. 4.

Infiltrative basal cell carcinoma.

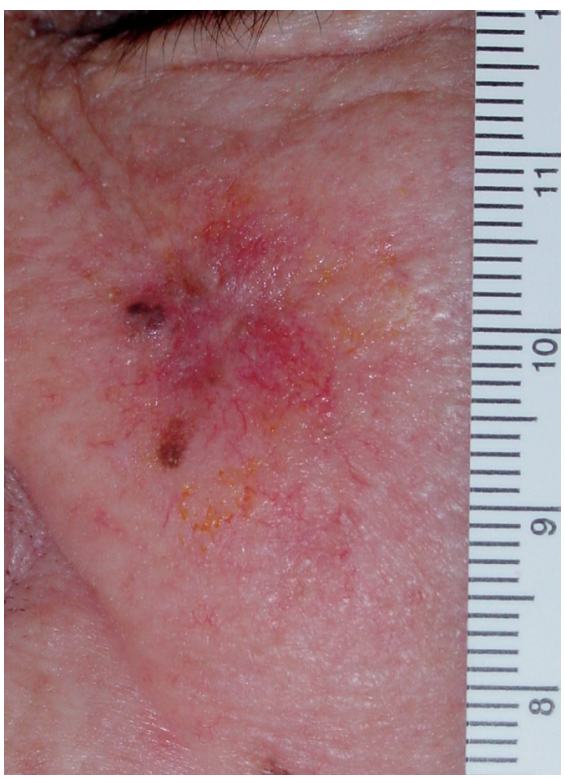

Fig. 5 .

Superficial basal cell carcinoma

(superficial multicentric basal cell carcinoma).

- Micronodular basal cell carcinoma: not clinically distinc tive, histologically micronodular growth pattern, curettage not indicated.

- Superficial basal cell carcinoma (superficial multicentric basal cell carcinoma) (Fig. 5): at least 15\% of BBCs; occurs most commonly on the trunk (40\%) or distal extremities (14\%) and grossly is an erythematous patch similar to ec zema or psoriasis; may grow to a large diameter and is the most common type of BCC in HIV patients.

- Pigmented basal cell carcinoma (Fig. 6): about $6 \%$ of all BCCs; similar in appearance to nodular BBC but with increased melanization (brown or black); common type of BCC in Asians.

- Rodent ulcer (Jacobi ulcer) (Fig. 7): untreated BCC that has formed ulceration. 


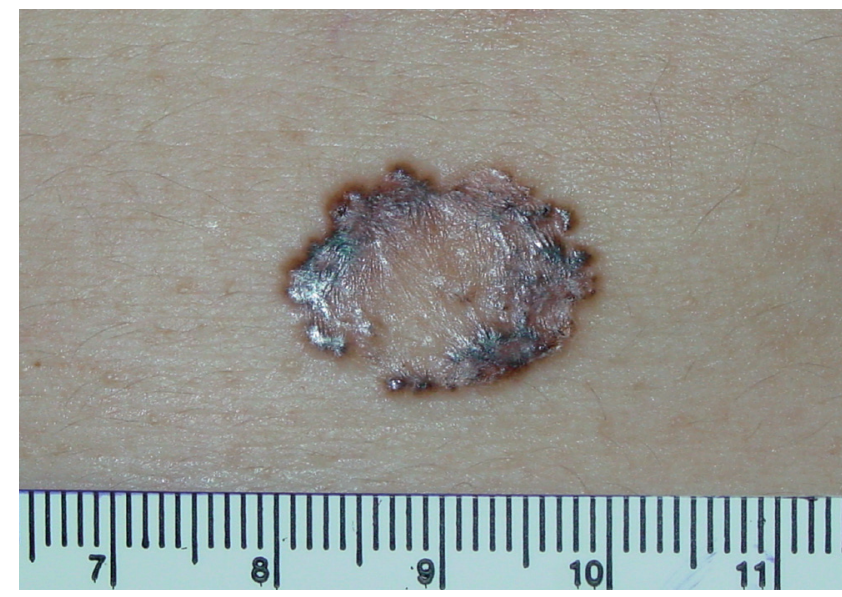

Fig. 6 .

Pigmented basal cell carcinoma.

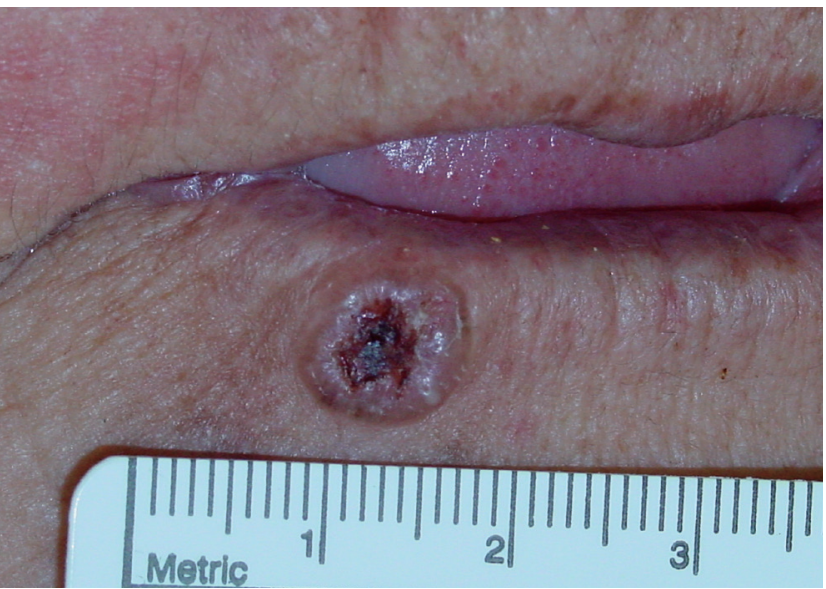

Fig. 7.

Rodent ulcer (Jacobi ulcer).

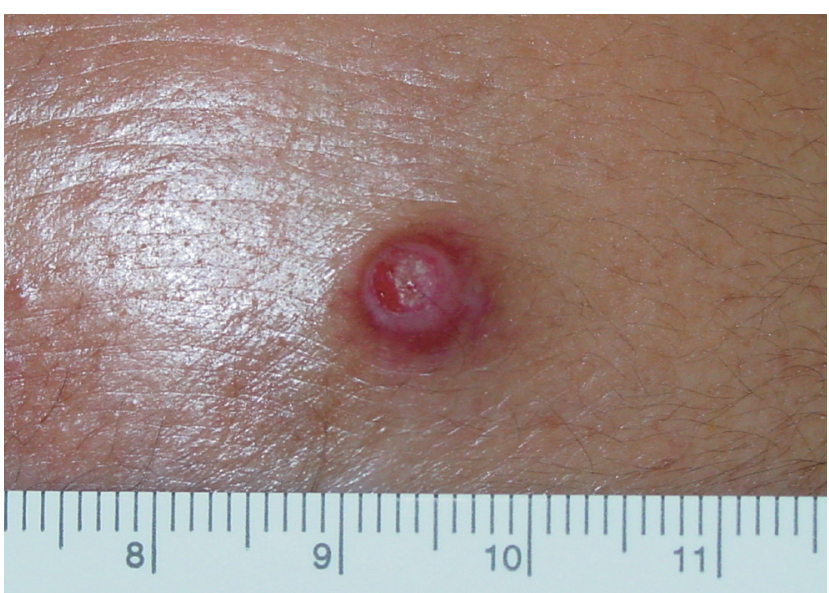

Fig. 8.

Fibroepithelioma of Pinkus.

- Fibroepithelioma of Pinkus (Fig. 8): most commonly oc curs on the lower back, groin, or thigh areas; may grow to

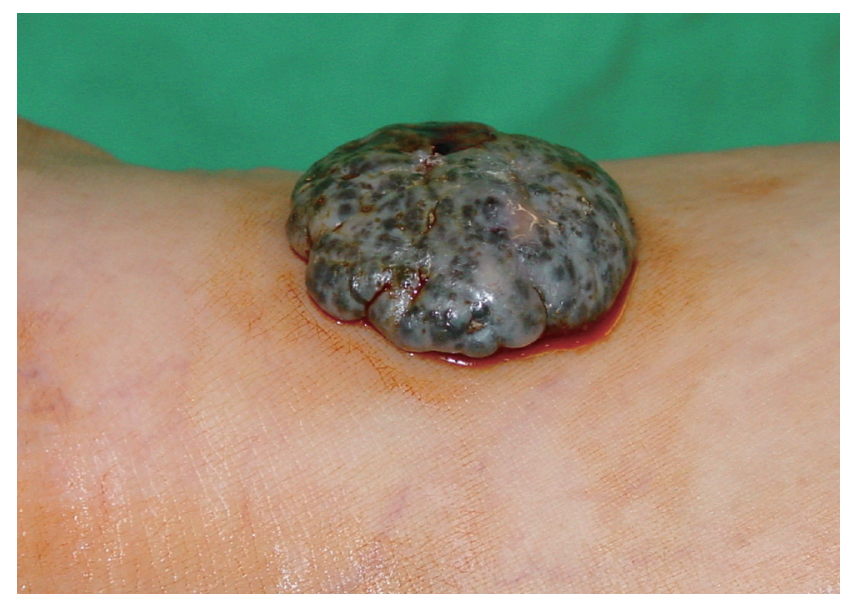

Fig. 9.

Polypoid basal cell carcinoma.

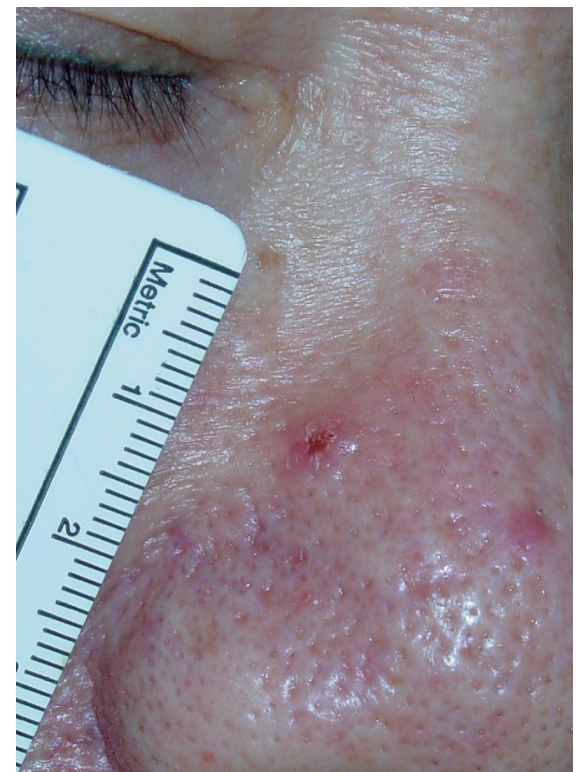

Fig. 10.

Pore-like basal cell carcinoma.

large size.

- Polypoid basal cell carcinoma (Fig. 9): characterized by exophytic nodules on the head and neck.

- Pore-like basal cell carcinoma (Fig. 10): usually found in thick sebaceous skin (nose, nasolabial fold, or lower fore head) and resembles an enlarged pore or stellate pit; gener ally in men and the majority are smokers.

- Aberrant basal cell carcinoma: absence of any apparent carci nogenic factor or occurring in odd sites such as the scrotum, vulva, perineum, nipple, or axilla.

- Solitary basal cell carcinoma in the young: occur in the region of facial embryonic clefts and are commonly deeply invasive. 


\section{STAGING}

Basal cell carcinoma metastasis is very rare; however, the American Joint Committee on Cancer's TNM system is the system most often used for staging [8].

Primary tumor $(\mathrm{T})^{*}$.

- TX: primary tumor cannot be assessed.

- T0: no evidence of primary tumor.

- Tis: carcinoma in situ.

- T1: carcinoma less than $2 \mathrm{~cm}$ in greatest dimension, with less than 2 high-risk features. ${ }^{* *}$

- T2: carcinoma greater than $2 \mathrm{~cm}$ in greatest dimension, or a tumor of any size with at least 2 high-risk features. ${ }^{* *}$

- T3: tumor invasion of the maxilla, mandible, orbit, or temporal bone.

- T4: tumor invasion of the skeleton (appendicular or axial) or with perineural involvement of the skull base.

${ }^{*}$ Excludes cutaneous squamous cell carcinoma of the eyelid.

**High-risk features for the primary tumor $(\mathrm{T})$ staging:

- Depth/invasion: >2 mm thickness, Clark level > IV, Peri neural invasion.

- Anatomic location: primary site ear, primary site non-hairbearing lip.

- Differentiation: poorly differentiated or undifferentiated.

Regional lymph nodes (N).

- NX: regional lymph nodes cannot be assessed.

- N0: no regional lymph node metastasis.

- N1: metastasis in a single ipsilateral lymph node, $3 \mathrm{~cm}$ or less in greatest dimension.

- N2: metastasis in a single ipsilateral lymph node, more than $3 \mathrm{~cm}$ but not more than $6 \mathrm{~cm}$ in greatest dimension; or in multiple ipsilateral lymph nodes, none more than $6 \mathrm{~cm}$ in greatest dimension; or in bilateral or contralateral lymph nodes, none more than $6 \mathrm{~cm}$ in greatest dimension.

- N2a: metastasis in a single ipsilateral lymph node, more than $3 \mathrm{~cm}$ but not more than $6 \mathrm{~cm}$ in greatest dimension.

- N2b: metastasis in multiple ipsilateral lymph nodes, none more than $6 \mathrm{~cm}$ in greatest dimension.

- N2c: metastasis in bilateral or contralateral lymph nodes, none more than $6 \mathrm{~cm}$ in greatest dimension.

- N3: metastasis in a lymph node, more than $6 \mathrm{~cm}$ in great est dimension.

Distant metastasis (M)

- M0: no distant metastasis.
- M1: distant metastasis.

Anatomic stage/prognostic groups.

- Stage 0 Tis, N0, M0

- Stage I T1, N0, M0

- Stage II T2, N0, M0

- Stage III T3, N0, M0

$\mathrm{T} 1$ to T3, N1, M0

- Stage IV T1 to T3, N2, M0

$\mathrm{T}$ any, N3, M0

T4, N any, M0

$\mathrm{T}$ any, $\mathrm{N}$ any, $\mathrm{M} 1$

\section{TREATMENT}

A biopsy should be performed in all lesions suspicious for BCC. The following are common methods used in the treatment of BCC: wide excision, curettage and electrodessication, Mohs micrographic surgery, cryosurgery, and radiation, while topical skin creams with imiquimod or 5-fluorouracil may be used to treat superficial basal cell carcinoma [9].

- Mohs micrographic surgery: single most effective technique for removing BCC.

- Wide excision: the standard surgical margins are 2 to $5 \mathrm{~mm}$ when previously untreated and about $1 \mathrm{~cm}$ or more for recur rent or large tumors. A frozen biopsy is mandatory to confirm sufficient tumor-free margins.

- Curettage and electrodessication: contraindicated for re current BCC.

- Cryosurgery: not recommended for large and recurrent tumors; less commonly used today.

- Radiotherapy: inoperable or recurrent tumors; for elderly and patients in poor health; contraindicated in the retreat ment of recurrent tumors following previous radiotherapy.

- Topical medications imiquimod or 5-fluorouracil: US FDAapproved for only superficial BCC, cure rate about $80 \%$ to $90 \%$.

\section{PROGNOSIS}

The 5-year recurrence rates for primary (previously untreated) BCCs are: surgical excision, $10.1 \%$; radiotherapy, $8.7 \%$; curettage and electrodessication, 7.7\%; cryotherapy, 7.5\%; all nonMohs modalities, 8.7\%; and Mohs micrographic surgery, $1 \%$. Recurrences usually occur 4 to 12 months after initial treatment, and the risk of developing a second lesion in 3 years is about $44 \%$, which is a 10 -fold increase over that of the general population $[10,11]$. Tumors on the nose or T-zone of the face have a higher incidence of recurrence. Recurrence is most common on 
the nose and nasolabial fold. Infiltrative, micronodular, and multifocal types have higher rates of recurrence than nodular types. Basal cell carcinoma rarely metastasizes ( $0.028 \%$ to $0.55 \%)$. The most common sites of metastasis are the lymph nodes, lungs, and bones. Patients who are diagnosed with BCC have a $35 \%$ chance of recurrence at the same site within 3 years and a $50 \%$ chance of developing another (not recurrent) BCC within 5 years [12].

\section{REFERENCES}

1. Wong CS, Strange RC, Lear JT. Basal cell carcinoma. BMJ 2003;327:794-8.

2. Casson PR, Robins P. Malignant tumors of the skin. In: McCarthy JG, editor. Plastic surgery. Philadelphia: WB Saunders Co.; 1990. p. 3615-17.

3. Lang PG, Maize JC. Basal cell carcinoma. In: Rigel DS, Friedman RJ, Dzubow LM, et al., editors. Cancer of the skin. Philadelphia: Elsevier Saunders; 2005. p. 101-32.

4. Wood GS, Gunkel J, Stewart D, et al. Nonmelanoma skin cancers: basal cell and squamous cell carcinomas. In: Abeloff $\mathrm{MD}$, Armitage JO, Niederhuber JE, et al., editors. Abeloff's clinical oncology. 4th ed. Philadelphia: Churchill Livingstone; 2008. p. 1253-70.

5. Von Hoff DD, LoRusso PM, Rudin CM, et al. Inhibition of the hedgehog pathway in advanced basal-cell carcinoma. $\mathrm{N}$ Engl J Med 2009;361:1164-72.

6. Casson PR, Robins P. Malignant tumors of the skin. In: McCarthy JG, editor. Plastic surgery. Philadelphia: WB Saunders Co.; 1990. p. 3619-23.

7. James WD, Berger TG, Elston DM, et al. Andrews' diseases of the skin: clinical dermatology. 10th ed. Philadelphia: Saunders Elsevier; 2006.

8. American Joint Committee on Cancer. Cutaneous squamous cell carcinoma and other cutaneous carcinomas. In: American Joint Committee on Cancer; American Cancer Society; American College of Surgeons. AJCC cancer staging manual. 7th ed. New York: Springer; 2010. p. 301-14.

9. Telfer NR, Colver GB, Morton CA, et al. Guidelines for the management of basal cell carcinoma. Br J Dermatol 2008; 159:35-48.

10. Marcil I, Stern RS. Risk of developing a subsequent nonmelanoma skin cancer in patients with a history of nonmelanoma skin cancer: a critical review of the literature and metaanalysis. Arch Dermatol 2000;136:1524-30.

11. Levi F, Randimbison L, Maspoli M, et al. High incidence of second basal cell skin cancers. Int J Cancer 2006;119:1505-7.

12. Lewis KG, Weinstock MA. Trends in nonmelanoma skin cancer mortality rates in the United States, 1969 through 2000. J Invest Dermatol 2007;127:2323-7.

\section{- CME Test : Basal Cell Carcinoma}

1. What is the most common type of basal cell carcinoma of the head and neck?
a) Nodular basal cell carcinoma
b) Superficial basal cell carcinoma
c) Morphoeic basal cell carcinoma
d) Cystic basal cell carcinoma

2. Which of the following treatment methods for basal cell carcinoma has the lowest 5-year recurrence rate?
a) Surgical excision
b) Radiotherapy
c) Cryotherapy
d) Mohs micrographic surgery

3. Which area has the highest rate of recurrence for basal cell carcinoma?
a) Forehead
b) Nose
c) Ear
d) Hand 